СУЧАСНА СИСТЕМА МІЖНАРОДНОГО ПРАВА

УДК 341.223.2(477.75):327.5(470)

\title{
REVISITING THE ISSUE ON THE EXTRATERRITORIAL EFFECT OF THE RUSSIAN LAW AND THE INTERNATIONAL LAW
}

\author{
ДО ПИТАННЯ ПРО ЕКСТЕРИТОРІАЛЬНУ ДІЮ \\ РОСІЙСЬКОГО ЗАКОНУ І МІЖНАРОДНЕ ПРАВО
}

\author{
К ВОПРОСУ ОБ ЭКСТЕРРИТОРИАЛЬНОМ ДЕЙСТВИИ \\ РОССИЙСКОГО ЗАКОНА И МЕЖДУНАРОДНОМ ПРАВЕ
}

\section{Zadorozhnii O. V.}

Doctor of Juridical Science, Professor, Head of the Department of International Law of the Institute of International Relations of Taras Shevchenko National University of Kyiv. E-mail: proxen2006@gmail.com

\section{Задорожній О. В.}

Доктор юридичних наук, професор, завідувач кафедри міжнародного права Інституту міжнародних відносин Київського національного університету імені Тараса Шевченка. E-mail: proxen2006@gmail.com

\section{Задорожний А. В.}

Доктор юридических наук, профессор, заведующий кафедрой международного права Института международных отношений Киевского национального университета имени Тараса Шевченко.

E-mail: proxen2006@gmail.com

Abstract. The article covers the issue of specific breaches of international law provisions owed to Ukraine by Russia. The article also examines problems in the application of international law by Russia. In the course of the Russian aggression against Ukraine, the former is carrying out the military occupation of the Crimean peninsula and parts of Donetsk and Luhansk regions and prosecutes Ukrainian citizens (Nadiya Savchenko, Oleh Sentsov, Oleksandr Kolchenko, Hennadii Afanasyev, Yurii Soloshenko and others) in violation of international law. Both Russian executives and doctrine attempt to substantiate the cases against Ukrainian citizens, however, their arguments suffer both legal and factual problems. An illustrative in this regard is Savchenko's case, which has become important Russian propaganda tool to help reinforce the accusations of the "atrocities committed by the Kyiv junta". The analyses shows that Savchenko case could have been used to complete different tasks - starting from lifting the sanctions imposed against the Russian Federation and finishing with increasing the number of Russian volunteers in the war against Ukraine.

Also, Russia has prosecuted Oleh Sentsov who has been charged with creating a terrorist group and committing two acts of terrorism.

One of the most untenable legal arguments of the Russian Federation is a qualification of the aggression as a non-international armed conflict. In this regard, Russian authorities and doctrine insist on Russia's not being bound or entitled to apply the rules of international armed conflicts laid down in the Geneva Convention relative to the Treatment of Prisoners of War (III) 
to Savchenko. At the same time, a considerable amount of data speaks for an aggressive war the Armed Forces of the Russian Federation launched against Ukraine in Donetsk and Luhansk regions. The Russian Federation has also grossly violated the norms of international humanitarian law and international human rights law.

Key words: The Russian Federation, Ukraine, Savchenko case, Investigative Committee of the Russian Federation, aggression, conflict, detention, imprisonment, Ukrainian citizens.

Анотація. У статті розглядається питання порушення норм міжнародного права з боку Росї по відношенню до Украӥни. У статті також аналізуються проблеми в застосуванні норм міжнародного права з боку Росії. В ході російської агресії проти України, перша здійснює військову окупачію Кримського півострова і частини Донецької $i$ Луганської областей і переслідує громадян Украйни (Н. Савченко, О. Сенцова, О. Кольченка, Г. Афанасьєва, Ю. Солошенка та інших) в порушення норм міжнародного права. Російське керівництво і доктрина намагаються обтрунтувати відкриття справ проти громадян України, однак, їхні аргументи юридично і фактично слабкі. Показовою в ияьому відношенні є справа Савченко, яка стала важливим інструментом пропаганди Росї для пояснення «звірств Київської хунти». Аналіз показує, щзо справа Савченко могла бути використана для виконання різних завдань - починаючи від скасування санкиій, введених проти Російської Федерачії, $i$ закінчуючи збільшенням числа російських добровольців у війні проти України.

Інший детально проаналізований в статті випадок зловживань Росї-справа проти О. Сенцова, який був обвинувачений у створенні терористичної групи і вчиненні двох терористичних актів.

Один з найбільш неприйнятних юридичних аргументів Російської Федерації є кваліфікація агресії як не міжнародного збройного конфлікту. У зв'язку з ции, російська влада і доктрина міжнародного права наполягають на тому, що держава не зв'язана нормами щуодо міжнародних збройних конфліктів, викладених в Женевській конвенції про поводження з військовополоненими (III) по відношенню до Савченко. У той же час, значна кількість фактів свідчить про агресивну війну Збройних Сил Російської Федераиії, розв 'язану проти Украӥни в Донещькій і Луганській областях. Росія також грубо порушила норми міжнародного гуманітарного права та міжнародного права в галузі прав людини.

Ключові слова: Росія, Украӥна, справа Савченко, Сліччй комітет Росії, агресія, конфлікти, затримання, ув'язнення, українські громадяни.

Аннотация. $B$ статье рассматривается вопрос нарушения норм международного права со стороны России по отношению к Украине. В статье также анализируются проблемы применения норм международного права со стороны России. В ходе российской агрессии против Украины, первая осуществляет военную оккупащию Крымского полуострова и части Донечкой и Луганской областей и преследует граждан Украины (Н. Савченко, О. Сенцова, А. Кольченко, Г. Афанасьева, Ю. Солоченко и других) в нарушение норм международного права. Российское руководство и доктрина пытаются обосновать открытие дел против граждан Украины, однако, их аргументы юридччески и фактически слабые. Показательным в этом отношении является дело Савченко, которое стало важным инструментом пропаганды России для объяснения «зверств Киевской хунтыл». Анализ показывает, что дело Савченко могло быть использовано для выполнения различных задач - начиная от отмены санкций, введенных против Российской Федерации, и заканчивая увеличением числа русских добровольцев в войне против Украиньл. 
Другой подробно проанализирован в статье случай злоупотреблений России - дело против О. Сенщова, который был обвинен в создании террористической группы и совершении двух террористических актов.

Один из самых неприемлемых юридических аргументов Российской Федерачии является квалификация агрессии как международного вооруженного конфликта. В связи с этим, российские власти и доктрина международного права настаивают на том, что государство не связана нормами по международным вооруженных конфликтов, изложенных в Женевской конвенции об обращении с военнопленными (III) по отнотению к Савченко. В то же время, значительное количество данных свидетельствует об агрессивной войне Вооруженных Сил Российской Федерачии, развязанную против Украины в Донеикой и Луганской областях. Россия также грубо нарушила нормы международного гуманитарного права и международного права в области прав человека.

Ключевые слова: Россия, Украина, дело Савченко, Следственный комитет России, агрессия, конфликты, задержания, заключения, украинские граждане.

The current problem. The various aspects of the research topic are covered by author's monographs "International law in the relations between Ukraine and the Russian Federation", "The violations by the aggressive war waged by the Russian Federation against Ukraine of the fundamental principles of international law", "The origin of international personality of Ukraine", "The annexation of Crimea is an international crime", "The international law doctrine of the Russian Federation following the annexation of Crimea". Also, representatives of global international legal doctrine, who have analyzed the violations of international law in respect of Ukraine by the Russian Federation, include Peter Ackerman, Maciej Bartowski, Anton Bebler, Chris Borgen, Michael Bothe, Daniel Wisehart, Marc Weller, Jure Vidmar, Shelagh Whitley, Christian Walter, and others. Among domestic scholars, who have considered this phenomenon are Volodymyr Butkevych, Ol'ha Butkevych, Viktor Brekhunenko, Volodymyr Vasylenko, Oleksiy Volovych, Bohdan Halaichuk, Mykola Hnatovskyy, Volodymyr Holovchenko, Volodymyr Horbulin, Pavlo Hrytsak, Yaroslav Dashkevych, and others.

The aim of the article is to analyze the violations of the Russian Federation of norms of international humanitarian law and international human rights law in the course of its war of aggression against Ukraine.

The important research results. An important component of the Russian war of aggression against Ukraine is the detention, arrest and imprisonment of Ukrainians on the occupied territories of Ukraine (Crimea, parts of Donetsk and Luhansk regions). This refers to Nadiya Savchenko, Oleh Sentsov, Oleksandr Kolchenko, Hennadii Afanasyev, Yurii Soloshenko and others. Nadiya Savchenko, a volunteer of Aidar Batallion [42], and an officer of the Ukrainian Armed Forces, was captured by militants on 18 June 2014 in the vicinity of Luhansk and handed over to the Russian authorities who put her in prison and opened a criminal case against her for alleged "involvement in the death of Russian journalists Ihor Kornelyuk and Anton Voloshin" [44].

On 7 July 2015, the charges against Savchenko were upgraded to "the murder of two Russian journalists in Donbas, not of complicity in this crime" [54].

Under the version of the Russian Federation Investigative Committee ('IC'), "Savchenko, being an officer of the Armed Forces of Ukraine, on 17 June 2014 conducted covert surveillance and correction of artillery fire on the site in the area of Metalist village of Slavyanoserbsk region (Luhansk oblast') shelling at the "LDR militia's" roadblock, where Russian journalists were. As a result of the shelling two Russians were killed" [66]. In March 2016, the Donetsk city court of the Rostov region found Savchenko guilty and sentenced her to 22 years in prison [67]. 
The charges against Savchenko are widely discredited given the circumstances of the case, including those which the IC has focused on. Inconsistencies inherent in the versions of the Russian government and the Russian media and can be seen in particular from how they describe the circumstances of Savchenko's detention. In July 2014, a Russian state-controlled NTV channel ("Gazprom-Media", a unit of Gazprom, owns it) [43] informed that Savchenko had been detained by "militia" and handed over to the Russian authorities [Shishkin, 2014].

However, later the Russian Federation has denied that Savchenko was detained in the territory of Ukraine, claiming that she had illegally crossed the Ukrainian-Russian border, to find herself in the territory of the Russian Federation "no later than 23 June 2014". On 9 July 2014, the Investigative Committee of the Russian Federation stated: “... With regard to the arrest of Savchenko, then, as it turned out, that under the guise of a refugee and without any ID she had crossed the border into Russia. She was purportedly stopped by a patrol in a residential area and detained for identification purposes. Later, it transpired that Savchenko was a suspect in a criminal case on charges of involvement in the killing of Russian journalists" [72].

On 23 July 2015, the official representative of the Russian IC Markin pointed out that "There is a theory that we have allegedly abducted Savchenko from somewhere. In fact, everything is very banal. She crossed the border of the Russian Federation, which is rather nominal I must admit. For a long time she was in the Voronezh region ... The investigation has the testimony of the two drivers, who gave her a ride; she lived in the hotel for quite a while ... Moreover, we have her handwritten statement addressing the Federal Migratory Service with a request to provide her with a document confirming the identity" [66].

Notwithstanding the above statements, during Savchenko's "trial" in the Rostov region the prosecution did not explain what had made her cross the border and settle in one of the hotels on the territory of the Russian Federation; how this fits with the status of refugee, with which Savchenko allegedly crossed the border; what she was going to do in the Russian Federation etc.

Naturally, they have nothing to say because these versions are absurd. The point is that the Russian investigation itself stuck to the version that Savchenko committed the crime deliberately. If to follow this logic, the alleged criminal, instead of staying low in the territory controlled by the Ukrainian authorities, went to Russia, where she had never been before, taking an awful chance of detention by Russian law enforcement agencies, which allegedly eventually happened. At the same time, Savchenko was wearing the Ukrainian military uniform, while "voluntarily staying in the territory of the Russian Federation".

Their arguments suffer from other inconsistencies as well. For example, according to the Investigative Committee of the Russian Federation, presented during the "trial", Savchenko was adjusting artillery fire near the village of Stukalova Balka. However, during the trial the representatives of the RF IC clarified that she was doing it alone, with a bullet through her hand, climbed onto a smooth steel tube towers unaided, in the rear of the militants, and then she got round them on the other side and was captured. Then the militants, without any reason, released Savchenko [Прусенкова, 2016].

The arguments of investigation look frankly unconvincing, even if we admit that the materials, on which they were based, deserve full confidence. On 6 July 2015, Vladimir Markin said, "Investigators calmly led the case to its logical ending, having collected the necessary body of evidence. I can only name the main ones. In the first place, it is the data of a forensic expert examination, which confirmed that Savchenko could have corrected the shell fire near the village of Metalist. Secondly, the results of a ballistic inquiry of shell fragments pulled out of the victims' bodies, confirming that it was a shell from D-30 howitzers. And thirdly, there are Savchenko's handwritten records and a detailed map of the area indicating her role in the military actions [73]. 
We draw attention to the fact that the opportunity to commit a crime and committing it - are completely different things, the results of ballistic tests do not indicate that Savchenko was involved in the murder of Kornelyuk and Voloshin. In addition, the materials of the case show that handwritten notes have not been confirmed as those of Savchenko and maps relate not to the village of Metalist but to the Ukrainian checkpoint near Vesela Hora, located 10 kilometres away [74].

The prosecution has ignored the fact that Savchenko was captured by the "militias" one hour before the journalists' deaths [62]. This is evidenced by billing data, i.e. information from the "defendant's" and Russian journalists' phones, connected to their location [Азар, 2016]. However, the court refused to place the alibi defence of Savchenko on file (the billings are simply excluded from the file) and refused to examine the video with Savchenko's staying in captivity, which would allow to determine the time by shadows and establish whether she was in captivity during the shelling. The court in its decision for some reason and without any elaboration pointed out that attempts to determine the time of detention by using video were untenable.

In addition, Kornelyuk and Voloshin entered the territory of Ukraine illegally, worked without accreditation, and were in military fatigues, with no protection and no media identification signs [Джанполадова, 2014], respectively, neither Savchenko, nor other participants of hostilities could, without any prior notice, identify them as journalists. The prosecution has not confirmed that Savchenko was aware of their presence in the territory.

Thus, none of the principal arguments of the prosecution, as the representatives of the investigation themselves put it, are validated.

The findings of the judgment that "Savchenko's guilt is confirmed by the testimony of witnesses, the court sees no contradictions in them; militia battalion "Zaria" has no reason to tar character Savchenko" are inconclusive [Ивахненко, 2014]. However, the failure of these findings is more than clear because we are talking about the representatives of the opposing party to an armed conflict, which is already more than sufficient reason for slander.

It is revealing that all of these contradictions have hardly been awarded the attention of the Russian law doctrine; the same applies to Savchenko case in general (the Russian information cover has basically been allotted to representatives of the investigation), although some of the studies deserve special consideration. The state and state-controlled media, in turn, reproduce the official position, adding "shocking details", namely, the "membership in the battalion known for looting and violence", that Savchenko's "hunger strikes" are nothing else but a gimmick to attract public attention" [73], "the involvement of Savchenko in the torture of the priest" $[\mathrm{Pe}$ месло, 2015], "Savchenko's idea to sell the organs of prisoners" [Балдина, 2014] and the like. The analysis of the above studies suggests that this case was an important Russian propaganda tool to help reinforce the accusations of the "atrocities committed by the Kyiv junta" that have been used and are used for a variety of tasks - from lifting the sanctions imposed against the Russian Federation, to increasing the number of Russian volunteers in the war against Ukraine.

As a result, the survey carried out by VTsIOM in Russia in March 2016, indicated that $45 \%$ of respondents believed that "Savchenko is an extreme nationalist who hates Russia", $18 \%$ of respondents expressed the view that "she is just a soldier on duty", $6 \%$ saw her as "a victim of circumstances". Every second respondent noted that Savchenko should be in prison for as long as the court decides; nobody, not even the president, should interfere with her destiny. Every third suggested that she should be exchanged for Russian citizens imprisoned in Ukraine. Sociologists have noted that Russians are roughly divided into two equal groups: one supports the court's decision, and the second seldom watches TV and does not follow the events [Варсегов, 2016]. 
In order to qualify the actions of the Russian Federation and the legal status of Savchenko after her capture in the territory of Ukraine, it is necessary to establish how to qualify the conflict and related events. Are we dealing with an international armed conflict or non-international armed conflict? Russian investigators and authors of studies consider the detention of Savchenko to be lawful, qualify the situation as non-international armed conflict, and the crimes imputed to her - the murder of civilians - citizens of the Russian Federation fall under the jurisdiction of the Russian Federation.

For example, Oleh Denisov puts this position in the following words: "International law knows two main types of armed conflicts - international armed conflicts and non-international armed conflicts.

The conflict in Donbas for obvious reasons is a non-international armed conflict, as hostilities occur between governmental armed forces and non-governmental armed groups, where such groups are under a certain command structure, have the capacity to sustain military operations and exercise control over a part of its territory...".

By the way, in an internal armed conflict between the government on the one hand and armed insurgent groups on the other the latter may be qualified as a "belligerent party" if they are self-organized and are responsible for the behaviour of their bodies, and established their authority on the part of the territory of a state. If the state of belligerency is recognized than certain participants in an armed conflict are insulated from prosecution and are entitled to prisoner of war ('POW') status.

However, Ukraine is in no hurry to officially recognize the belligerency of Donetsk People's Republic ('DPR') and Luhansk People's Republic ('LPR') and hasn't ceased prosecution of certain arrested insurgents for "terrorism". Even the Minsk agreements, behind which Western advocates of Savchenko tend to hide, do not explicitly provide thereto. Therefore, it is groundless to demand from the rebels to grant the captured Aidar battalion militia a POW status.

But the most important thing is that there is no international armed conflict between Ukraine and the Russian Federation. Therefore, Russia is neither bound nor entitled to apply the rules of international armed conflicts laid down in the Geneva Conventions to Savchenko. Nadiya Savchenko is simply prosecuted for a serious criminal offense against civilians" [Лебедева, 2016].

These findings are contrary to the content of norms of international law and factual circumstances. This article together with a number of foreign studies argues that the conflict between Russia and Ukraine is an international armed conflict.

It should be reminded that the qualification of an armed conflict as international, contrary to the opinion of Denisov and other Russian scholars, in accordance with international law does not depend on an official recognition: under the Geneva Conventions of 1949 this is not a question of recognition but of actual circumstances [Денисов, 2016]. Article Two common to all Geneva Conventions of 1949 (the Convention for the Amelioration of the Wounded and Sick in Armies (I) [7], the Convention for the Amelioration of the Condition of Wounded, Sick and Shipwrecked, Members of Armed Forces at Sea (II) [8], the Convention relative to the Treatment of Prisoners of War (III) [9], the Geneva Convention relative to the Protection of Civilian Persons in Time of War (IV)) [10] provides for an international law definition of an "international armed conflict". It is envisaged that international armed conflict ('IAC') is armed conflict between two states $[7 ; 8 ; 9 ; 10]$.

The International Criminal Tribunal for the former Yugoslavia ('ICTY') has articulated a general definition of an international armed conflict. Considering the Dusko Tadic case, the ICTY found that "an armed conflict exists whenever there is a resort to armed force between States". This definition was upheld by other international bodies [11]. 
This approach is generally characteristic of the representatives of the world doctrine of international law. Sams determines an international armed conflict as a conflict in which one state uses arms against another state, regardless of the reasons or the intensity of the confrontation [Sams, 2011: 62].

As Dietrich Schindler notes, "the existence of an armed conflict within the meaning of Article 2 common to the Geneva Conventions can always be assumed when parts of the armed forces of two States clash with each other. [...] Any kind of use of arms between two States brings the Conventions into effect" [Schindler, 1979: 131]. Hans-Peter Gasser explains that "any use of armed force by one state against the territory of another, triggers the applicability of the Geneva Conventions between the two states. [...] It is also of no concern whether or not the attacked party resists" [Gasser, 1993: 510-511].

The latter is particularly important in light of the consideration of the seizure of the territory of Ukraine (the Crimean peninsula) by the Russian Federation and the detention of the citizens of Ukraine - Oleh Sentsov, Oleksandr Kolchenko and others, and the speculation of Russian leaders that there was no armed aggression in Crimea, as there was no fighting [71].

Representatives of the Russian doctrine of international law follow the approach of foreign scholars. Anatoly c qualifies armed clashes between states, conflicts in which peoples are fighting against colonial domination, alien occupation and racist regimes in the exercise of their right to self-determination as enshrined in the UN Charter and other international instruments as international armed conflicts [Талалаев, 1999: 531]. Hennadii Melkov believes that an international armed conflict is an armed confrontation between states, between national liberation movements and colonialist, between the occupier and the occupied territories [Мелков, 2003: 568].

As Denys Shlyantsev defines it, international armed conflicts are such conflicts, in which one subject of international law uses armed force against another subject. Thus, the parties to an international armed conflict may be states, nations and peoples fighting for independence, international organizations engaged in collective military measures for maintaining peace and international order [Шлянцев, 2008: 208].

A considerable amount of data speaks for an aggressive war the Armed Forces of the Russian Federation launched against Ukraine in Donetsk and Luhansk regions. Furthermore, under international law all the actions of the so-called "rebels" are attributed to Russia, which is substantiated by two respective international legal doctrines - the doctrine of effective control and the doctrine of overall control. The articles emphasize that the Russian Federation continues to officially deny the use of force against Ukraine, which, of course, precludes its legitimacy. Thus, under international law, Savchenko should be considered a prisoner of war.

In our opinion, the attention should be paid to the arguments of the Russian lawyer Hleb Bogush, who while analyzing Savchenko's case in the context of the qualification of the conflict, said that "In assessing the conflict from the perspective of international humanitarian law, the arguments speaking for the international character of the conflict should be recognized more convincing, at least for the simple reason that in case of an irresolvable doubt as the doctrine and existing practice suggest (for example, in a situation of conflict in the former Yugoslavia), the regime providing for greater protection to participants of the conflict should be granted. The latter refers exactly to the rules of international armed conflict.

Hence, in case of a doubt regarding the qualification of a conflict, the legal rules of international conflicts should apply, because they are more humane and obligations of the parties are clearly spelt out. Moreover, the arrest and trial of Savchenko in Russia is rather an additional argument in favour of qualifying the conflict as an "internationalized"' [Богуш, 2016]. 
Based on this, the crime imputed to Savchenko cannot qualify as an ordinary criminal offense; it is a war crime - the murder of civilians, which under the Geneva Conventions, should be considered by special military courts. Therefore, the Russian "investigation" in this regard suffers from serious contradictions. On the one hand, in May 2015 Savchenko's case was separated from the general criminal case of "genocide perpetrated by Ukrainian law enforcement and security services and the use of prohibited means and methods of warfare".

On the other hand, the Russian Investigative Committee administration charged the Ukrainian national under Article 33, Part 5 and Article 105, Part 2, Points A, B, E, F and L of the Russian Criminal Code (complicity in the killing of two or more people in the line of duty committed by means dangerous to the public on grounds of political hatred committed by a group of persons) [68].

The Russian Federation has also grossly violated the norms of international humanitarian law and international human rights law. Illegal detention, custody and imprisonment of Nadiya Savchenko are a breach of the provisions of Article 5 "The right to liberty and security" of European Convention on Human Rights of 1950 [4] by Russia.

Council of Europe Parliamentary Assembly considered the imprisonment of Savchenko in terms of her PACE membership. For example, in Resolution № 2034 (2015) "Challenge, on substantive grounds, of the still not ratified credentials of the delegation of the Russian Federation" of 28 January 2015, the Assembly expressed serious concern about the imprisonment and indictment by the Russian Federation of Ms Nadiya Savchenko, who is now a member of the Assembly.

The Assembly considers her transfer by Ukrainian insurgents to the Russian Federation and subsequent imprisonment by the Russian authorities to be in violation of international law amounting to her de facto kidnapping. It demands that the Russian Federation respect its obligations under international law, as a Party to the General Agreement on Privileges and Immunities of the Council of Europe [6] and its protocol [14], according to which according to which Ms Nadiya Savchenko, as a member of the Parliamentary Assembly, enjoys European parliamentary immunity [5]. The Assembly calls upon the Russian authorities to release Ms Savchenko within 24 hours and to ensure her return to Ukraine or hand her over to a third country.

The position of the representatives of the Russian authorities and the legal doctrine is that the "attempts to make the case political took place from the outset: first they made her a deputy of the Rada and a representative in the Parliament Assembly of the European Council hoping to use functional immunity to release her, but they forgot that it doesn't work in such cases" [74].

Expanded description of these theses contains statements that "documents of the Council of Europe do not provide exemption from criminal liability in connection with the membership in PACE. Article 40 of the Statute of the Council of Europe sets 'immunities shall include immunity for all Representatives to the Consultative (Parliamentary) Assembly from arrest and all legal proceedings in the territories of all Members, in respect of words spoken and votes cast in the debates of the Assembly or its committees or commissions'. Savchenko's immunity does not apply to actions committed before she acquired her status as an Assembly delegate, while the crimes imputed to the Ukrainian national were committed before the elections and cannot be considered reasonably necessary for the fulfilment of her functions in PACE" [Денисов, 2016].

The same opinion was expressed by Illia Remeslo: "Russian law does not allow for an exemption from criminal liability in connection with the membership in PACE. It is also not provided for in the Council of Europe Statute governing the PACE immunity issues. Article 40 of the Statute states that representatives of Members and the Secretariat shall enjoy in the territories of its Members such privileges and immunities as are reasonably necessary for the fulfilment of their functions. These immunities shall include immunity for all Representatives to the Con- 
sultative (Parliamentary) Assembly from arrest and all legal proceedings in the territories of all Members, in respect of words spoken and votes cast in the debates of the Assembly or its committees or commissions". Article 14 of the General Agreement on Privileges and Immunities of the Council of Europe contains a similar provision.

The immunity applies only in respect of words spoken and votes cast in PACE debates. Savchenko committed the alleged offense long before being "elected" to PACE, and is has nothing to do with her activities in PACE. And the charge had been brought against her before she became a deputy. Otherwise, it would mean that any person, who has committed a serious crime, may then get the status of a deputy and become immune to any prosecution in his own country or abroad" [Ремесло, 2015].

However, international law speaks against the above position. A narrow interpretation of immunity is incorrect. In accordance with Article 15 of the General Agreement on Privileges and Immunities of the Council of Europe of 1949, of which both the Russian Federation and Ukraine are parties, During the sessions of the Consultative Assembly, the Representatives to the Assembly and their substitutes, whether they be members of Parliament or not, shall enjoy a) on their national territory, the immunities accorded in those countries to members of Parliament; $b$ ) on the territory of all other member States, exemption from arrest and prosecution. This immunity also applies when they are travelling to and from the place of meeting of the Consultative Assembly.

It does not, however, apply when Representatives and their substitutes are found committing, attempting to commit, or just having committed an offence, nor in cases where the Assembly has waived the immunity. However, according to the circumstances of the case this provision does not apply to Savchenko.

The 1952 Protocol to the Agreement of 1949 (Article 5) stipulates that privileges, immunities and facilities are accorded to the representatives of members not for the personal benefit of the individuals concerned, but in order to safeguard the independent exercise of their functions in connection with the Council of Europe. Consequently, a member has not only the right but the duty to waive the immunity of its representative in any case where, in the opinion of the member, the immunity would impede the course of justice and it can be waived without prejudice to the purpose for which the immunity is accorded [1]. The latter provision does not apply to Russia's actions in relation to Savchenko, since she is not the representative of the Russian Federation, and the lifting of immunity is clearly contrary to the purpose for which the immunity is granted.

It is important that Savchenko is judged as a representative of Ukraine, and not as a random individual, which is confirmed by the actions of the Russian leadership and the Investigative Committee of Russia. The case against Savchenko was severed from the general criminal case over genocide and use of prohibited means and methods of warfare by Ukrainian militaries to form a separate lawsuit.

The foregoing does not mean that the death of journalists should not be investigated. The point is that Savchenko is not supposed to be kept in custody and prosecuted in Russia.

For a long period of time (since the summer of 2014 until the spring of 2016) the indignation at the actions of the Russian authorities of the international community had no effect on its stance [46]. This also holds for the acts of the EU [47], international organizations [69], statements of world leaders, demanding the immediate release of Nadiya Savchenko [12].

Savchenko has finally refused to submit the appeal to the European Court of Human Rights ('ECtHR'). She could lodge a complaint when on 1 July 2015 Moscow City Court upheld the decision to extend the arrest of Savchenko [48]. The application, Savchenko v. Russia, was lodged with the Court on 14 July 2014, it has been granted priority; the court president also for- 
warded questions to the Russian government as to how did Nadia Savchenko get into the Russian pre-trial detention centre [79]. However, after the sentencing in March 2016 Savchenko refused to appeal in order to not waste time. It is practically impossible for the ECtHR to consider the case of her arrest.

On the other hand, the issue of Savchenko has drawn international condemnation, which is obviously much more effective than any rulings of the ECtHR. On 24 April 2016, Poroshenko announced that agreement had been reached on the step-by-step approach and procedures of releasing Nadiya Savchenko, but no actual steps have been taken so far by the Russian side. However, on 28 April 2016, Russian representatives reported that Savchenko was to sign documents for extradition to Ukraine [44]. On 3 May 2016, Savchenko's lawyer Polozov mentioned [64] the approval by the authorities of the decision to transfer her to Ukraine under the Convention on the Transfer of Sentenced Persons of 1983 under the accelerated procedure [78].

As a result, de facto the return of Nadiya Savchenko to Ukraine was exchanged for the return of Russian Special Forces officers Oleksandr Alexandrov and Evhen Yerofeyev who were found guilty of committing crimes on the territory of Ukraine [3].

Even in this respect, Russia's position in relation to Savchenko is inconsistent because she was branded an extremely dangerous criminal who had committed a felony against journalists, which could not allow for a release, for almost two years.

Thus, in July 2015 the representative of the Russia's IC stated that "Nobody made any audible legal argument of protection but only banal accusations of investigators of forgery and attempts to make the case political. To do that they first wanted to make Savchenko a prisoner of war, which she is not, and them they made her a deputy of the Rada and a representative in the Parliament Assembly of the European Council hoping to use functional immunity to release her, but they forgot that it doesn't work in such cases. Not to mention a hunger strike the Ukrainian was advised to use to press the investigators and public opinion. In other words, Savchenko's supporters basically used non-juridical actions for sole purpose of releasing the accused of a felony" [74].

On 22 March 2016, the famous Russian State Duma Deputy Iryna Yarovaya, commenting on the verdict against Nadiya Savchenko, stressed "The sentence was passed in strict accordance with the law, according to the established legal procedures and in full compliance with international law. On the basis of the rules stipulating that journalists are subject to special protection... Murder committed in order to prevent the legitimate activities of Russian journalists in a truthful coverage of events in Donbas is a particularly serious crime, this 'merit' is not political but criminal, and, therefore, the adequate responsibility is criminal, proportionate and just ... Russia's position on the protection of journalists' freedom of activity is the position aimed at protecting the common humanitarian values. We see that wherever in the world these values are neglected terrible crimes occur. Therefore, our common task is to be equally tough with murderers just like with terrorists".

Perhaps the Russian Federation switchover is due to the desire to a) provide additional arguments for easing sanctions against the Russian Federation; b) prevent the key witnesses of the Russian aggression against Ukraine from the number of Russian troops from testifying.

Another example of illegal actions of the Russian Federation is the detention, trial and conviction of Ukrainian director Oleh Sentsova and other citizens of Ukraine on suspicion of "plotting terrorist acts".

Ukrainian filmmaker Oleh Sentsov was detained in Crimea by the Russian FSB on 10 May 2014 under charges of establishing a terrorist organization under the order of the "Right Sector" movement. The FSB reported the detention of Sentsov and three more activists, alleged members of the "Right Sector" on 30 May 2014 [55]. However, the movement denied membership 
of Sentsov, and in the course of proceedings the defence took a certificate signed by the head of the "Right Sector" Dmytro Yarosh to the court, according to which the person of interest had never been in his organization [Демидюк, 2014].

The Russian investigation claimed Afanasyev, Chyrniy, Kolchenko, Borkin, Zuikov, Asanov and Cyril were participants of the criminal group. Chyrniy and Afanasyev were convicted and Borkin, Zuikov, Asanov and Cyril were declared wanted [51].

Russia's Federal Security Service accused the four Ukrainians of being "part of a terrorist community, operating in Simferopol, Sevastopol' and Yalta, which planned to carry out explosions with home-made devices on 9 May 2014 near the Eternal Flame memorial and Lenin monument in Simferopol and to set on fire the offices of the Russian Community of Crimea public organization and the United Russia party branch in Simferopol on 14 April and 18 April 2014 [58].

On this basis, Sentsov was charged with creating a terrorist group (Article 205.4 paragraph 1 of the Criminal Code of Russia), committing two acts of terrorism (subparagraph 'a' paragraph 2 of Article 205 of the Criminal Code of Russia), preparing to commit two terrorist attacks (paragraph 1, Article 30 and subparagraph 'a' paragraph 2 of Article 205 of the Criminal Code), as well as two episodes of illicit trafficking in firearms and explosives (paragraph 3 of Article 222 of the Criminal Code) [63], Oleksandr Kolchenko, in his turn, was charged with involvement in the terrorist community, and committing a terrorist act.

Oleksandr Kolchenko admitted that he had been at the office of the United Russia on the night of 18 April 2014, but he had not thrown Molotov cocktails (as argued by the representatives of the Federal Security Service), and in any event he did not consider this act an "act of terror". As Kolchenko defense lawyer Novikov believed "the fundamental question is not what those people did and what they did not do but what intentions they invested in an action. The Russian investigation claimed that it was a terrorist activity; thereby a group that was going to be engaged in the systematic organization of terrorist acts was created. In my opinion, this is not visible" [17].

In addition to illegal detention, search and seizure of personal belongings, Sentsov was tortured to obtain confessions [Нехезин, 2015]. Though traces of violence were recorded by employees of the detention centre in Simferopol, the Investigative Committee of the Russian Federation refused to open an investigation of violence against him, ridiculously explaining the injuries by his assumed previous S\&M leanings. The conditions of the further detention of the accused were unsatisfactory as well [17].

On 25 August 2015, the court in Rostov-on-Don sentenced Sentsov to 20 years and his "accomplice" Kolchenko - to 10 years in prison [Светова, 2014]. At the end of February 2016 they were transferred to the colony in the Chelyabinsk region [52].

The charges against Sentsov and Kolchenko were primarily based on the testimony of Afanasyev and Chirnyi, who immediately after the arrest, began to cooperate with the investigation. Sentsov certainly was not anywhere close to the site of two arson attacks, so the Russian investigation were tasked to obtain not a simple testimony of Chirnyi and Afanasyev, but their testimony against Sentsov as the manager of the "group" who gave the order to organize attacks" [65].

Afanasyev was himself abducted by the FSB in early May 2014 and taken to a Moscow jail "Lefortovo", informally controlled by the secret service. Later, according to unconfirmed sources Afanasyev was accused of all the episodes of the case. He allegedly was the liaison between Sentsov and Chirnyi - the fourth and last of the defendants in the case at hand. Afanasyev allegedly participated in the coordination of the production of bombs. It was reported that he had 
made a confession and refused to use the services of independent lawyers [53]. In December 2014, Moscow City Court found him guilty and sentenced to 7 years in prison [51].

The materials of the investigation led by the FSB were classified; the lawyers singed a nondisclosure agreement. One of them informed that there was no other evidence linking Sentsov to the "terrorist organization" except for the testimony of the "accomplices" - no wiretaps, no operational search activities materials [56]. During the interrogation Afanasyev claimed that his testimony was forced [59], and later he described in detail what tortures he was subjected to [61], while Chirniy refused to answer the questions of the parties during the trial [51]. It should be noted that Kolchenko also reported torture during the investigation; Sentsov reported attempts to extract the necessary confessions. He was severely beaten, strangled with a bag and threatened with rape $[51 ; 60]$.

It is puzzling how the FSB qualifies the motive of committing the above-mentioned "crimes": "The destabilization of the socio-political situation on the peninsula and influence on authorities of the Russian Federation decision-making on the secession from the Republic of Crimea" [41], especially given the fact that the stance of Russia has not even shaken by a threat of severe international sanctions and exclusion from international organizations.

Indicative are the courtroom addresses of other witnesses and victims, who were involved in the process via video link from Crimea (functionary of "Russian Community of Crimea" Kozenko, who burned the door in the office, and a former member of the "Crimean self-defence" Bochkarev, representing "United Russia" in court). Bochkarev failed to fulfil the demand of the court to produce documents substantiating the assessment of the damage. The defence team noted that in April 2014, "United Russia" was not registered in Crimea, and the office was registered under a different legal entity.

Both victims were unable to clearly answer questions about exactly how the arsons "destabilized the situation" in the country and how they could "influence the decision to secede from the Russian Federation", and whether "Right Sector" was present in Crimea. Bochkarev could remember only that some people in the spring of 2014 "left unpleasant writings on the fence like "Crimea is Ukraine!".

Also, via a video conference the parties questioned "Russian community" guard Filippenko, who put out the burning office door, and firemen - Baraban, Andruhin and Konoval, who put out fire in the "United Russia" premises. Witness Konoval noted that "at the time it was the office of the Party of Regions". An activist of "Young Guard "United Russia"' Purtov and bartender Chernyi, a supporter of the GCD of the State Duma deputy Fedorov, were witnesses for the prosecution. The latter told the court that the "Right Sector" is "one of the structural divisions of the United States" [61].

On 25 August 2015, the North Caucasus District Military Court sentenced Oleh Sentsov to 20 years imprisonment in a penal colony, Oleksandr Kolchenko was sentenced to 10 years of the colony [75]. On 24 November 2015, the Supreme Court of Russia upheld the sentences of Sentsov and Kolchenko [57]. One cannot but pay attention to what off-beats are the terrorists in this case: Sentsov is a filmmaker, Chirniy is a historian, Afanasyev is a lawyer and Kolchenko is an activist.

In March 2016, Sentsov's lawyer lodged an appeal against the verdict [50], and already announced his intention to make recourse to the ECtHR upon passing through all instances in Russia $[80]$.

The question of appeal to the ECtHR in the case of Kolchenko and Sentsov was decided differently than in the case of Savchenko. On 26 August 2015, Arseniy Yatsenyuk announced Ukraine's intention to submit the fourth application to the Court against Russia in connection with the sentencing of Sentsov [Ногаева, 2015]. The next day, Pavlo Petrenko stated that a 
claim on the illegal sentencing of Sentsov and other Ukrainians by Russia had already been submitted to the ECtHR (“Ukraine against Russia (IV)") [77].

In April 2015, Oleksandr Kolchenko filed an application to the ECtHR against Russia on illegal detainment and compulsory acquisition of Russian citizenship (violation of Article 8 of the ECHR). The applicant pointed out the physical impossibility of such acquiring of Russian citizenship, because he was in jail in the corresponding period in 2014 [Корня, 2015]. Oleh Sentsov's attorney announced the submission of a similar claim to the ECtHR, because the former had been forced to change his citizenship as well [76; 69; 12].

Negotiations for the release of Sentsov and other Ukrainians illegally deprived of their liberty by the Russian Government continue. The world leaders, the EU and international organizations have called for their release for a number of times already [53].

However, so far, only Afanasyev and another prisoner of the Russian Federation Yuri Soloshenko have been released. They were pardoned by Putin on 14 June 2016 by respective orders. Soloshenko's case was also under the FSB investigation. He was accused of allegedly wanting to steal secret documents from Russia - the documents themselves being designs of C300 antiaircraft systems for the Ministry of Defence of Ukraine. In October 2015, Moscow City Court sentenced the 73-year-old man to 6 years in prison for "espionage" [47].

Lawyer of Soloshenko and Afanasyev Polozov explained that the motives of their release were that they were both sick, "For the Kremlin authorities costs on their possible death in custody in Russia would have been much higher than in the case of their exchange. Let us hope that in the result of urgent, intensive medical care Afanasyev and Soloshenko will get better" [49]. The Russian Federation exchanged them for the defendants in the case on the tragic events in Odessa on 2nd May 2014 Evheny Mefedov and Elena Glishchinskaya [70], who could also be actively engaged as "witnesses of the nationalists' atrocities in Odessa".

As for Oleh Sentsov, on 14 June 2016, Dmitry Peskov said that the contacts on a prisoner exchange are carried out including on the nomination of Oleh Sentsov but on the part of Russia the final decision will be made by Vladimir Putin [Томин, 2016].

The analysis of Russia's actions gives good reasons for asserting its treatment of Sentsov, Kolchenko and other captured Ukrainians as hostages, who can be "traded" to obtain certain concessions from Ukraine and international community regarding, for example, sanctions and other restrictions, and, secondly, to use them as part of their public outreach programme. This is the same tactic that has already been applied in the case of Savchenko, when she was exchanged for Russian military Yerofeyev and Aleksandrov who participated in the aggression against Ukraine. Prior to that, "Savchenko case" was used as a propaganda tool to illustrate "atrocities of Kyiv junta".

From the international law standpoint, an international armed conflict is ongoing between Ukraine and the Russian Federation since February 2014. In the course of the conflict Russia is carrying out the military occupation of the Crimean peninsula and parts of Donetsk and Luhansk regions provided, however, the Russian Federation is obliged to observe international humanitarian law and international human rights law in the occupied territories. The actions in relation to the citizens of Ukraine, such as Nadiya Savchenko, Oleh Sentsov, Oleksandr Kolchenko, Hennadii Afanasyev breach international law provisions.

Violations include torture, prohibited by Article 5 of the Universal Declaration of Human Rights of 1948 [16], Article 7 of the International Covenant on Civil and Political Rights of 1966 [15] and Article 3 of the Convention on the Protection of Human Rights and Fundamental Freedoms of 1950; illegal arrests and imprisonment (Articles 3 and 9 of the 1948 Declaration, Article 9 of the 1966 Covenant, Article 5 of the 1950 Convention); deprivation of the right to fair trial (Article 10 of the 1948 Declaration, Article 14 of the 1966 Covenant, Article 6 of the 
1950 Convention); interference with privacy, family, encroachment on inviolability of the home, correspondence, honour and reputation (Article 12 of the 1948 Declaration, Article 17 of the 1966 Covenant, Article 8 of the 1950 Convention), propaganda of national, racial or religious hatred that constitutes incitement to discrimination, hostility or violence shall be prohibited by law (Article 20 of the 1966 Covenant, Article 14 of the 1950 Convention) [9;10].

With regard to international humanitarian law, the Russian Federation primarily violated the Geneva Convention relative to the Treatment of Prisoners of War of 1949 (Article 13 of humane treatment of prisoners, Article 14 on respect for the person of prisoners, Article 15 of the maintenance of prisoners, Section II : Internment of prisoners of war and others) [9], and the Geneva Convention relative to the protection of Civilian Persons in Time of War of 1949 (Article 27 on the right to respect for their person, their honour, and humane treatment, Article 31 on non-exercise of physical or moral coercion, Article 32 on the prohibition of taking any measure of such a character as to cause the physical suffering, Article 49 on the prohibition of individual or mass forcible transfers of protected persons from occupied territory to the territory of the Occupying Power, Article 72 on the right to a fair trial and some others) [10].

On the other hand, the Russian actions are clear, gross and systematic violations of fundamental principles of international law such as the principle of the protection of human rights and fundamental freedoms; the principle of sovereign equality of states (Ukraine is prosecuted for its policy in the face of Savchenko and Sentsov, however, one state cannot prosecute another); non-interference in the internal affairs of states (the persecution of Ukrainians is an attempt to destabilize the domestic political situation in Ukraine).

Conclusions. Thus, the Russian Federation measures of detention, arrests, sentencing and imprisonment of Savchenko, Sentsov, Kolchenko and other citizens of Ukraine in connection with the Russian-Ukrainian conflict during the 2014-2016 do not comply with international law. Russia clearly, grossly and systematically violates a number of fundamental rules of international humanitarian law and international human rights law. Citizens of Ukraine are used, firstly, as hostages to get concessions (for example, the lifting of sanctions), and, secondly, as an antiUkrainian propaganda tool, which is an important component of the war of aggression against Ukraine. The cases against Ukrainians are designed, among other things, to convince the Russian military in the correctness of their participation in the war, and to promote the recruitment of volunteers.

\section{References}

1. Council of Europe, Chart of signatures and ratifications of Treaty 002 General Agreement on Privileges and Immunities of the Council of Europe as of 23 June 2016, <http:// www.coe.int/en/web/conventions/full-list/-/conventions/treaty/002/signatures?p_auth= $\mathrm{CI} 3 \mathrm{hDHe} 0>$

2. Council of Europe, Convention for the Protection of Human Rights and Fundamental Freedoms, Strasbourg, 4 November 1950, <http://www.echr.coe.int/Documents/Convention_ ENG.pdf>

3. Council of Europe, Convention on the Transfer of Sentenced Persons, Strasbourg, 21 March 1983, European Treaty Series 112, <https://rm.coe.int/CoERMPublicCommonSearchServices/DisplayDCTMContent?documentId=0900001680079529>

4. Council of Europe, European Convention on Human Rights as amended by Protocols Nos. 11 and 14 supplemented by Protocols Nos. 1, 4, 6, 7, 12 and 13, Rome, 4 November 1950, $<$ http://www.echr.coe.int/Documents/Convention_ENG.pdf $>$ 
5. Council of Europe, Resolution 2034 (2015). Final version. Challenge, on substantive grounds, of the still unratified credentials of the delegation of the Russian Federation, $<$ http://assembly.coe.int/nw/xml/XRef/Xref-XML2HTML-EN.asp?fileid=21538\&lang=en>

6. General Agreement on Privileges and Immunities of the Council of Europe, Paris, 2 September 1949, European Treaty Series 2, 1950, <https://rm.coe.int/CoERMPublicCommonSearchServices/DisplayDCTMContent?documentId=0900001680063729>

7. ICRC, Convention (I) for the Amelioration of the Condition of the Wounded and Sick in Armed Forces in the Field. Geneva, 12 August 1949, <https://ihl-databases.icrc.org/applic/ihl/ihl.nsf/7c4d08d9b287a42141256739003e636b/fe20c3d903ce27e3c125641e004a92f 3>

8. ICRC, Convention (II) for the Amelioration of the Condition of Wounded, Sick and Shipwrecked Members of Armed Forces at Sea. Geneva, 12 August 1949, <https://ihl-databases.icrc.org/ihl/INTRO/370?OpenDocument>

9. ICRC, Convention (III) relative to the Treatment of Prisoners of War. Geneva, 12 August 1949, <https://ihl-databases.icrc.org/applic/ihl/ihl.nsf/7c4d08d9b287a42141256739003 e63bb/6fef854a3517b75ac125641e004a9e68>

10. ICRC, Convention (IV) relative to the Protection of Civilian Persons in Time of War. Geneva, 12 August 1949, <https://ihl-databases.icrc.org/ihl/INTRO/380>

11. ICTY, The Prosecutor v. Dusko Tadic. Decision on the Defence Motion for Interlocutory Appeal on Jurisdiction, IT-94-1-A, 2 October 1995, <http://www.icty.org/x/cases/tadic/ acdec/en/51002.htm>

12. OSCE, Resolution on Abducted and Illegally Detained Ukrainian Citizens in the Russian Federation, 7 July 2015, < https://www.oscepa.org/meetings/annual-sessions/2015-helsinkiannual-session/2015-helsinki-final-declaration/2291-16>

13. OSCE, Resolution on the Continuation of Clear, Gross and Uncorrected Violations of OSCE Commitments and International Norms by the Russian Federation, 8 July 2015, <https:// www.oscepa.org/meetings/annual-sessions/2015-annual-session-helsinki/2015-helsinkifinal-declaration/2282-07>

14. Protocol to the General Agreement on Privileges and Immunities of the Council of Europe, Strasbourg, 6 November 1952, European Treaty Series 10, 1952, <https://rm.coe.int/CoERMPublic Common SearchServices/Display DCTMContent?documen$\mathrm{tId}=09000016800637 \mathrm{a} 2>$

15. United Nations, International Covenant on Civil and Political Rights, New York, 16 December 1966, Treaty Series 999, <https://treaties.un.org/doc/publication/unts/volume\% 20999/volume-999-i-14668-english.pdf>

16. ООН, Всеобщая декларащия прав человека от 10 декабря 1948 г. [The Universal Declaration of Human Rights, 10 December 1948], <http://www.un.org/ru/universal-declaration-human-rights/>

17. Уголовный кодекс Российской Федерации. Федеральный закон № 63-ФЗ от 13 июня 1996 г. [The Criminal Code of the Russian Federation. Federal Law No. 63-FZ, 13 June 1996], <http://docs.cntd.ru/document/9017477>

18. Gasser H. P. (1993) 'International humanitarian law: An introduction', in H. Haug (ed.) Humanity for all: The International Red Cross and Red Crescent Movement, P. 510-511. Berne: Paul Haupt Publishers.

19. Sams K. (2011) 'Involvement of the peace operation as the party to the armed conflict', in M. Odello, R. Piotrowicz (eds.) International military missions and international law. Leiden: Martinus Nijhoff Publishers. 
20. Schindler D. (1979) 'The different types of armed conflicts according to the Geneva conventions and protocols', RCADI 163: 121-163.

21. Shishkin P., Alpert I. L. (2014) 'Pro-Russia rebels defiant as Ukraine military advances toward Donetsk', The Wall Street Journal, 10 July, <https://www.wsj.com/articles/ukraineforces-take-another-rebel-held-town-1404996939>

22. Азар И. (2016) "Я ее взял и лично передал Плотницкому”. Боец ЛНР рассказал 'Медузе', как задерживали Надежду Савченко' [“I detained her and personally handed over to Plotnitskii'. The DPR fighter told 'Meduza' how Savchenko had been detained], 21 марта, <https://meduza.io/feature/2016/03/21/ya-ee-vzyal-i-lichno-peredal-plotnitskomu>

23. Балдина A. (2014) 'Украинский плен' [Ukrainian captivity], Вести.ру, 17 сентября, $<$ http://www.vesti.ru/doc.html?id=1977850>

24. Богуш Г. (2016) 'Подмена обвиняемого. Юридический анализ дела Савченко' [Substitution of the accused person. Legal analysis of the Savchenko's case], Московский центр Карнеги, 21 марта, <http://carnegie.ru/publications/?fa=63081>

25. Варсегов H. (2016) 'Протоиерей Владимир Марецкий, побывавший в плену у нацгвардейцев: “Савченко предлагала продать пленных на органы”' [Archpriest Vladimir Maretskii to have been kept prisoner by the national guards: "Savchenko proposed to sell the organs of the prisoners"], Комсомольская правда, 11 марта, <http://www.kp.ru/daily/ $26503 / 3371540 />$

26. Демидюк Н. (2014) 'ФСБ: Украинский режиссер Сенцов готовил теракты вместе с активистами 'Правого сектора" [Federal Security Service of the Russian Federation: Ukrainian film director Sentsov prepared terrorist attacks together with the activists from the 'Right Sector'], Московский комсомолеи, 30 мая, <http://www.mk.ru/social/2014/05/30/fsbukrainskijj-rezhisser-sentsov-gotovil-terakty-vmeste-s-aktivistami-pravogo-sektora.html>

27. Денисов О. (2016) ‘Дело Савченко: отделить право от пиара' [Savchenko's case: To separate the law from the PR], Русская Idea, 16 марта, <https://politconservatism.ru/articles/delo-savchenko-otdelit-pravo-ot-piara>

28. Джанполадова Н., Гостев А. (2014) 'Алиби Надежды Савченко' [Nadezhda Savchenko’s alibi], Радио Свобода, 17 декабря, <http:/www.svoboda.org/a/26748995.html>

29. Ивахненко В., Сетдикова Д. (2014) 'Командировка на смерть' [Deadly business trip], Радио Свобода, 18 июня, <http://www.svoboda.org/a/25426694.html>

30. Корня A. 'Крымчанин пожаловался в ЕСПЧ на принудительное присвоение российского гражданства' [Crimean complained to the ECHR of the forced conferment of the Russian citizenship], Ведомости, 8 апреля 2015 г., <http:/www.vedomosti.ru/politics/articles/2015/04/09/krimchanin-pozhalovalsya-v-espch-na-prinuditelnoe-prisvoenie-rossiiskogo-grazhdanstva>

31. Лебедева Н. (2016) 'Россияне вынесли свой вердикт по делу Надежды Савченко' [Russians rendered their verdict in the case of Nadezhda Savchenko], Российская газета, 29 марта, <https://rg.ru/2016/03/29/rossiiane-vynesli-svoj-verdikt-po-delu-nadezhdy-savchenko.html>

32. Мелков Г. (2003) 'Международное право в период вооруженных конфликтов’ [The international law in the period of armed conflicts] in К. Бекяшев (ed.) Международное публичное право [International public law]. Москва: Проспект.

33. Нехезин B. (2015) ‘Дело Сенцова: в чем обвиняют режиссера?' [The case of Sentsov: What is the film director accused of?], Русская служба ВВС, 21 июля, <http://www.bbc. com/ukrainian/ukraine_in_russian/2015/07/150721_ru_s_sentsov_trial_beginning $>$ 
34. Ногаева K. (2015) 'Украина подает в Европейский суд по правам человека в связи с делом Сенцова' [Ukraine files a claim to the European Court of Human Rights due to the case of Sentsov], Deutsche Welle, 26 августа, <http://www.dw.com/ru/украина-подает-вевропейский-суд-по-правам-человека-в-связи-с-делом-сенцова/а-18673493>

35. Прусенкова Н. (2016) 'Я уже имею право на все' [I already have the right to all], Новая газета 30, 23 марта, <https://www.novayagazeta.ru/articles/2016/03/22/67893-171-yauzhe-imeyu-pravo-na-vse-187>

36. Ремесло И. (2015) ‘Была ли наводчица? Пять заблуждений о деле Савченко’ [Was there a gun-layer? Five delusions regarding the Savchenko's case], РИА Новости, 6 апреля, $<$ http://ria.ru/analytics/20150406/1056853941.html>

37. Светова 3. (2014) 'Олег Сенцов и другие 'крымские террористы' [Oleg Sentsov and other 'Crimean terrorists'], Открытая Россия, 23 сентября, <https://openrussia.org/post/ view/228/>

38. Талалаев А., Тункин Г., Шестаков Л. (1999) Международное право [International law]. Москва : 'Юридическая литература' Администрации Президента Российской Федерации.

39. Томин Д. (2016) 'Кремль подтвердил контакты с Украиной по обмену Сенцова' [The Kremlin confirmed its contacts with Ukraine regarding the exchange of Sentsov], Московский комсомолеи, 15 июня, <http://www.mk.ru/politics/2016/06/15/kreml-podtverdil-kontakty-s-ukrainoy-po-obmenu-sencova.html>

40. Шляниев Д. А. (2008) Международное право: курс лекций [International law: The course of lectures]. Москва: Юстицинформ.

41. ВВС Україна, Сенщов: “Мене били стоячи, лежачи, сидячи” [Sentsov: "I was beaten when I stood, lay, sat”], 6 серпня 2015 p., <http://www.bbc.com/ukrainian/politics/ 2015/08/150806_sentsov_trial_upd_sx>

42. ВВС Україна, У Росії Савченко заарештували до кіния літа [In Russia, Savchenko was arrested till the end of summer], 9 липня 2014 p., <http://www.bbc.com/ukrainian/politics/2014/07/140709_savchenko_update_arrest_dt $>$

43. ВВС. Русская служба, Кто владеет СМИ в России: ведущие холдинги [Who owns the mass media in Russia: Leading holdings], 11 июля 2014 г., <http://www.bbc.com/russian/russia/2014/07/140711_russia_media_holdings>

44. Interfax Report, ECHR sends inquiry to Russia concerning Ukrainian pilot Savchenko case, 16 July 2014.

45. Joinfo, European Parliament calls on Russia to immediately liberate Oleksandr Kolchenko and Oleg Sentsov, 10 September 2015, <http://joinfo.com/world/1008442_european-parliament-calls-on-russia-to-immediately-liberate-oleksandr-kolchenko-and-oleg-sentsov. html>

46. Kyiv Post, Pilot Savchenko gets parliamentary mandate, 25 November 2014, <https://www. kyivpost.com/article/content/oct-26-parliamentary-election/pilot-savchenko-gets-parliamentary-mandate-373094.html>

47. Ministry of Foreign Affairs of Ukraine, European Parliament resolution on Russia, in particular the cases of Eston Kohver, Oleg Sentsov and Olexandr Kolchenko, 10 September 2015, <http://mfa.gov.ua/en/news-feeds/foreign-offices-news/39933-jevroparlament-uhvaliv-rezolyuciju-na-pidtrimku-ukrajinciv-nezakonno-uvjaznenih-v-rf $>$

48. U.S. Department of State, Continued detention of Nadiya Savchenko. Press Statement: John Kerry, Secretary of State, Washington, DC, 7 March 2016, <https://2009-2017.state.gov/secretary/remarks/2016/03/254054.htm> 
49. Аналитическая служба новостей, Полозов рассказал, почему Путин отпустил Афанасьева и Солошенко [Polozov told why Putin had released Afanasiev and Soloshenko], 14 июня 2016 г., <http://asn.in.ua/ru/news/news/51017-polozov-rasskazal-pochemu-putinotpustil-afanaseva.html $>$

50. Ведомости, Адвокаты Олега Сенцова подали кассацию на приговор [Oleg Sentsov's defence lawyers filed a cassation against the verdict], 28 марта 2016 г., $<$ http://www.vedomosti.ru/politics/news/2016/03/28/635344-sentsova-kassatsiyu>

51. Газета.ru, В 'Правом секторе' опровергли причастность к ним режиссера Сенцова [The 'Right Sector' confuted complicity of the film director Sentsov for their activities], 30 мая 2014 г., <http://www.gazeta.ru/social/news/2014/05/30/n_6194765.shtml>

52. Грани, Приговор Сенцову и Кольченко [Sentence for Sentsov and Kolchenko], 25 августа 2015 г., <http://graniru.org/Politics/Russia/Politzeki/m.243792.html>

53. Грани.ру, В знак признательности. Крымский узник Геннадий Афанасьев приговорен $\kappa$ семи годам колонии [As a token of appreciation. The Crimean prisoner Gennadii Afanasiev is sentenced to seven years in prison], 25 декабря 2014 г., $<$ http://graniru.org/Politics/Russia/Politzeki/m.236340.html>

54. Интерфакс, В СКР заявили о грозящих Савченко 25 годах тюрьмы [The Investigative Committee of the RF announced that Savchenko was impended 25 years in prison], 13 июля 2015 г., < ttp://www.interfax.ru/russia/453408>

55. Интерфакс, Обмен Савченко на Ерофеева и Александрова оформили через проиедуру помилования [Exchange of Savchenko for Yerofeiev and Alexandrov was officially registered through the pardon process], 25 мая 2016 г., <http://www.interfax.ru/russia/510084>

56. Интерфакс, Путин помиловал Солошенко и Афанасьева [Putin pardoned Soloshenko and Afanasiev], 14 июня 2014 г., <http://www.interfax.ru/russia/513420>

57. Интерфакс, Суд подтвердил приговор Сенщову по делу о подготовке терактов в Kpblмy [The Court confirmed the sentence for Sentsov in the case on the preparation of terrorist attacks in Crimea], 24 ноября 2015 г., <http://www.interfax.ru/russia/481216>

58. Медиазона, Проиессс Сенизова. День первыцй [Sentsov’s process. The first day], 21 июля 2015 г., <https://zona.media/online/2015/21/07/sentsov-nachalo>

59. Медиазона, Проиесс Сениова. Допрос Афанасьева [Sentsov's process. The interrogation of Afanasiev], 21 июля 2015 г., <https://zona.media/online/2015/31/07/sentsov-afanasev>

60. Медиазона, Процесс Сенцова. Приговор [Sentsov's process. The sentence], 25 августа 2015 г., <https://zona.media/online/2015/25/08/protsess-sentsova-prigovor>

61. Обозреватель, “Били, щуоб не було синців”: Афанасьєв розповів про тортури ФСБ ["They beat me in order no bruises left": Afanasiev described the FSS tortures], 17 червня 2016 p., $<$ https://www.obozrevatel.com/ukr/crime/13264-bili-schob-ne-bulo-sintsiv-afanasev-rozpoviv-pro-torturi-fsb.htm>

62. Обозреватель, Дело Савченко: адвокат раскрыл 'притянутые за уши' доказательства. Опубликованы документы [Savchenko's case: The lawyer disclosed the 'far-fetched' evidence], 28 августа 2015 г., <https://www.obozrevatel.com/crime/95721-delo-savchenkoadvokat-podrobno-rasskazal-o-prityanutyih-za-ushi-dokazatelstvah--opublikovanyi-dokumentyi.htm>

63. Пресс-служба Федеральной службы безопасности Российской Федерации, На территории Республики Крым сотрудниками ФСБ России задержаны члены диверсионно-террористической группь 'Правого сектора' [In the territory of the Republic of Crimea the FSS of the RF officers detained members of the 'Right sector' sabotage-terror- 
ist group], 30 мая 2014 г., <http://fsb.ru/fsb/press/message/single.htm!id\%3D10437554\% 40fsbMessage.htm>

64. РИА Новости Украина, Порошенко заявил, что договорился с Путинылм о сроках освобождения Савченко [Poroshenko declared that he had agreed with Putin on the date of Savchenko's release], 24 апреля 2016 г., <http://rian.com.ua/politics/20160424/10089 54454.html>

65. РИА Новости Украина, Сенцова этапировали в колонию в Челябинской области [Sentsov was transferred to the prison colony in the Cheliabinsk region], 4 марта 2016 г., $<$ http://rian.com.ua/society/20160304/1006195830.html>

66. РИА Новости, Маркин: Савченко никто не похищал, она сама перешла гранииу с РФ [Markin: Nobody kidnapped Savchenko, she crossed the border with the RF by herself], 23 июля 2015 г., <http://rian.com.ua/russia/20150723/371056600.html>

67. РИА Новости, Приговор Савченко: 22 года в российской колонии и штраф [Savchenko's sentence: 22 years in the Russian prison and a fine], 22 марта 2016 г., <https://ria.ru/incidents/20160322/1394869448.html>

68. РИА Новости, Уголовное дело гражданки Украины Надежды Савченко [The criminal case of the citizen of Ukraine Nadezhda Savchenko], 21 марта 2016 г., <http://ria.ru/ spravka/20160302/1381923155.html>

69. Росбалт, Пушков: Иммунитет в ПАСЕ не несет для Савченко никаких последствий [Pushkov: The PACE immunity does not carry any consequences for Savchenko], 27 января 2015 г., <http://www.rosbalt.ru/main/2015/01/27/1361397.html>

70. Сегодня.иа, Афанасьев и Солошенко дали свое первое интервью после освобождения [Afanasiev and Soloshenko gave their first interview after the release], 18 июня 2016 г., $<$ http://www.segodnya.ua/politics/pnews/afanasev-i-soloshenko-dali-svoe-pervoe-intervyuposle-osvobozhdeniya-725680.html $>$

71. Сегодня.иа, В МИД РФ заявили, что аннексия Крыма и конфликт в Донбассе - это не нарушение Будапештского меморандума [The RF Ministry of Foreign Affairs announced that the annexation of Crimea and the conflict in the Donbass are not the violation of the Budapest Memorandum], 31 марта 2015 г., <http://www.segodnya.ua/politics/ pnews/v-mid-rf-zayavili-chto-anneksiya-kryma-i-konflikt-v-donbasse-eto-ne-narusheniebudapeshtskogo-memoranduma-599484.html>

72. Следственный комитет Российской Федераци, Гражданке Украины Надежде Савченко предъявлено обвинение в пособничестве в убийстве журналистов ВГТРК [Тhe citizen of Ukraine Nadezhda Savchenko was charged with the accessory in the murder of journalists of the VGTRK], 9 июля 2014 г., <http://sledcom.ru/news/item/523081>

73. Следственный комитет Российской Федерации, Завершено расследование уголовного дела в отношении обвиняемой Надежды Савченко [The investigation of the criminal case against the accused Nadezhda Savchenko is completed], 6 июля 2015 г., <http://sledcom.ru/news/item/944210>

74. Следственный комитет Российской Федерации, Обвиняемая Надежда Савченко завершила ознакомление с материалами уголовного дела [The accused Nadezhda Savchenko has completely familiarized with the materials of the criminal case], 2 июля 2015 г., <http://sledcom.ru/news/item/942978>

75. ТАСС. Информационное агентство России, Украинского режиссера Сениова приговорили к 20 годам колонии за теракты в Крыму [The Ukrainian film director Sentsov was sentenced to 20 years in prison for the terrorist attacks in Crimea], 25 августа 2015 г., $<$ http://tass.ru/proisshestviya/2209192> 
76. Тиждень.иа, ДМС: Затриманий кримський активіст Сенцов має украйнське громадянство [State Migration Service of Ukraine: Detained Crimean activist Sentsov has the citizenship of Ukraine], 7 квітня 2014 p., <http://tyzhden.ua/News/133726>

77. Укрінформ, Справа Сенияова: Україна подала до Свросуду позов до Росї [The case of Sentsov: Ukraine has filed a lawsuit against Russia to the European Court of Human Rights], 26 августа 2015 г., <https://www.ukrinform.ua/rubric-iac/1877457-sprava_sentsova_ukraiina_podala_do_e_vrosudu_pozov_do_rosiii_2088082.html >

78. УНИАН, Адвокат Савченко заявил, что прочесс ее передачи не займет полгода [Savchenko's defence lawyer stated that the process of her transfer would not take six months], 3 мая 2016 г., <https://www.unian.net/society/1336602-nadejda-stolko-jdat-nemojet-advokat-savchenko-zayavil-chto-protsess-ee-peredachi-ne-zaymet-polgoda.html>

79. УНИАН, Защита Савченко получила юридические основания обратиться в ЕСПЧ адвокат [Savchenko's defence obtained legal grounds to apply to the ECHR - the defence lawyer], 2 июля 2015 г., <https://www.unian.net/politics/1096128-zaschita-savchenkopoluchila-yuridicheskie-osnovaniya-obratitsya-v-espch-advokat.html>

80. УНИАН, Зашита Сенцุова и Кольченко будет обращзаться в ЕСПЧ, если апелляция по делу будет отклонена [Sentsov's and Kolchenko's defence will apply to the ECHR if the appeal on the case is dismissed], 25 августа 2016 г., <https://www.unian.net/politics/1115233-zaschita-sentsova-i-kolchenko-budet-obraschatsya-v-espch-esli-apellyatsiyapo-delu-budet-otklonena.html> 